\title{
Countermeasures for Financing Difficulties of SMEs
}

\author{
Danyang Li \\ School of Management and Economics \\ Beijing Institute of Technology \\ Beijing, China
}

\begin{abstract}
As an important component of China's economic system, the key to the steady development of small and mediumsized enterprises is the scientific development of financing. However, from the current financing activities of small and medium-sized enterprises, financing difficulties are still the main problem facing their financing activities. In this regard, this paper will analyze the causes of financing difficulties of SMEs, and draw up solutions to improve the financing difficulties of SMEs, and enhance the economic development vitality of SMEs.
\end{abstract}

Keywords-SMEs; financing problems; solutions

\section{INTRODUCTION}

With the gradual activation of China's market economy, the reform of social and economic system has brought unprecedented opportunities for the development of SMEs. As an important part of economic system, SMEs, which account for $99.6 \%$ of the total number of enterprises in China, have provided $60 \%$ of the gross national product for China's economic construction, and paid more than $50 \%$ of the taxes of China's enterprises. This shows that SMEs are an integral part of China's economic construction, and it is an urgent task for China's economic construction to ensure their development under the macro background of economic new normal. However, from the perspective of actual situation of the development of SMEs, they still face the practical problem of financing difficulties in terms of the financing stage. If the financing activities of SMEs are not smooth enough, it will seriously threaten their liquidity reserve status and also further threaten their long-term development. In this regard, we should have a detailed understanding of the specific circumstances of SMEs' financing difficulties, and formulate corresponding solutions, so as to ensure the smooth development of financing activities for SMEs, which is a key issue for the development of enterprises at this stage as well as the main content of this paper.

\section{SUMMARY OF FINANCING FOR SMES}

\section{A. Definition of Financing}

The enterprise financing has broad and narrow definitions. In a broad sense, financing is the behavior that an enterprise raises funds and lends money by some means in the financial market to obtain working capital fund [1]. In a narrow sense, starting from the operation status of SMEs, enterprise financing mainly refers to the behavior that an enterprise raises funds from internal and external investors and creditors for the development and business activities of enterprises by mastering their operating conditions, financial status and future development potential and making them public. Notably, it is very important for SMEs to take note of risk control, scientific financing, reasonable planning and effective cost arrangement in financing activities. To ensure that financing activities are planned and effective, we can not only improve the actual effect of financing, but also reduce the impact of potential financing risks on the development of enterprises to a certain extent.

\section{B. Types of Financing}

On the basis of grasping the concept of enterprise financing, this paper analyzes the basic types of enterprise financing, including endogenous financing and exogenous financing [2]. Endogenous financing mainly means that an enterprise obtains the working capital required for its operation by raising and collecting internal capital. This financing method will not change the total amount of internal capital of the enterprise and can better save financing costs. However, the disadvantage is the limited amount of financing, so the financing effect varies due to the amount or number of capital demand. On the contrary, exogenous financing mainly refers to that enterprises apply for financial support from external economic entity based on development considerations and support enterprise's internal business activities through capital integration. The current forms of exogenous financing mainly include bank loan, stock issuance and sales of bonds. However, according to the data disclosed by China Business Network, it can be found that the proportion of endogenous financing in Chinese enterprises is much higher than that of exogenous financing, and the specific situation is shown in the table.

TABLE I. The Proportion OF FINANCING OPTIONS FOR SMES IN CHINA

\begin{tabular}{|l|l|l|l|l|l|}
\hline \multirow{2}{*}{} & \multirow{2}{*}{$\begin{array}{c}\text { Endogenous } \\
\text { Financing }\end{array}$} & $\begin{array}{c}\text { Bank } \\
\text { loan }\end{array}$ & $\begin{array}{c}\text { Private } \\
\text { lending }\end{array}$ & $\begin{array}{c}\text { Business } \\
\text { credit }\end{array}$ & Others \\
\hline $\begin{array}{l}\text { Proporti } \\
\text { on }\end{array}$ & $78.1 \%$ & $9.65 \%$ & $5.07 \%$ & $3.25 \%$ & $3.93 \%$ \\
\hline
\end{tabular}

\section{The CAUSES OF SMEs' FINANCING DifFICULTIES}

On the basis of mastering relevant financing materials of SMEs, this paper analyzes the main causes of financing difficulties faced by SMEs in China, which can be summarized into the following two aspects: 


\section{A. Internal Limitations Cause the Financing Difficult}

Among the causes of financing difficulties of SMEs, enterprises' internal limitation is one of the keys that cannot be ignored. The limited internal development of SMEs makes their financing less attractive, resulting in their financing difficulties.

1) Unreasonable governance structure: When SMEs conduct financing activities, enterprise credibility is the key to ensuring the financing effect of enterprises, but the core of determining enterprises' external public image is the optimization of enterprise governance structure, clarity of development direction, and orderly development of internal organization, equity structure, and operating efficiency [3]. However, as far as the governance structure of SMEs in China is concerned, taking Shaanxi as an example, Shaanxi Small and Middle-sized Enterprise Bureau has cooperated with local commercial departments to investigate the internal governance structure of SMEs in this region, and the results are shown in "Fig. 1". Limited liability companies occupy the largest proportion, reaching $71.45 \%$, and individual proprietorship accounts for $28.43 \%$, while joint-stock companies only account for $0.12 \%$. Based on this, individual proprietorship, limited liability companies, and other companies are very easy to become a family business. Nepotism exists at all levels of management in many SMEs. Compared with the scientific governance policy, the governance idea based on human relations and family affection first is more deep-rooted, which leads to unclear relations between departments in terms of rights, responsibilities and interests, and insufficient implementation of governance rules between departments at all levels. This further results in loose internal structure of the company, problems in stock right planning and insufficient guarantee of operating efficiency, and finally gives rise to various investors' worries about the enterprise's future development and dissatisfaction with the credibility of enterprise financing, and then affects SMEs' financing.

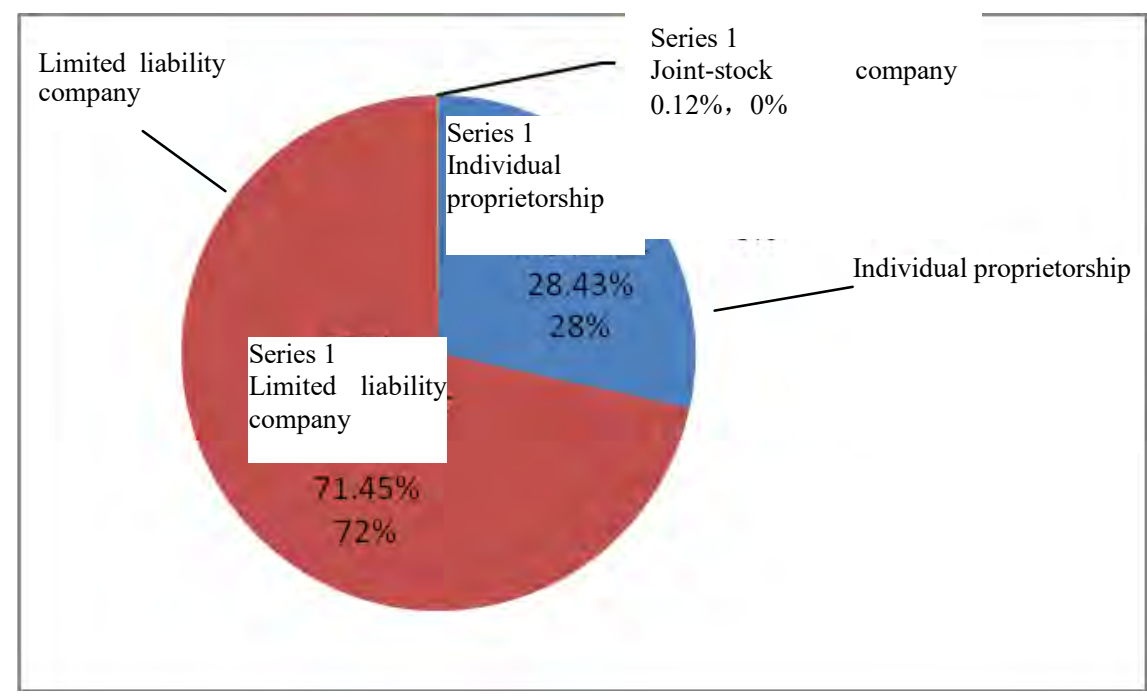

Fig. 1. Schematic diagram of proportion of the company's structure.

2) Irregular financial management: In the development of financing activities of SMEs, the irregular financial management also affects the credibility of enterprise financing [4]. Because of the family governance structure, many SMEs are reluctant to release their financial management power, but appoint relatives for management. However, these relatives who are entrusted with important tasks often have limited financial management quality, weak awareness of financial disclosure, insufficient cognition of risk assessment, and even limited attention to responsibility. They will follow the instructions of their managers, tamper with company accounts for their own sake, and regard national laws as nothing. In the case of insufficient management norms, large financial institutions including banks will reduce their trust in such enterprises due to material problems, clarity of enterprise operation and other problems when approving loans for them, and slow down the investment, ultimately resulting in financing difficulties of SMEs.

\section{B. External Causes Lead to Financing Difficulties}

Compared with internal limitations, the financing difficulties of SMEs caused by external reasons are more urgent. The financing difficulties of SMEs caused by external factors are the important reasons why SMEs can not obtain better financing capital.

1) Insufficient support from financial institutions: For financial institutions, ensuring investment profits is the core objective of their operations. For this reason, compared with projects with high investment risk such as SMEs, more financial institutions are willing to invest funds in large enterprises and large-scale projects to ensure the scientificity of capital investment and rational use of funds [5]. Certainly, 
according to relevant data, the success rate of SMEs' loan application in China can reach $79.9 \%$ when financial institutions (mainly banks) approve their application, which means that only $20.1 \%$ of loan applications are rejected. Nevertheless, when we carefully study this data, we can find that among the $20.1 \%$ of SMEs rejected, small and micro businesses are dominant, and many of them are newly started and newly established enterprises. These enterprises are badly in need of financing to consolidate their development foundation, but banks refuse to lend money, so what is waiting for them is to close down. In this regard, banks also have no choice. Considering the profit problem, there is a high risk in investing in SMEs, so financial institutions have limited interest in supporting SMEs, which is also the main reason for financing difficulties of SMEs.

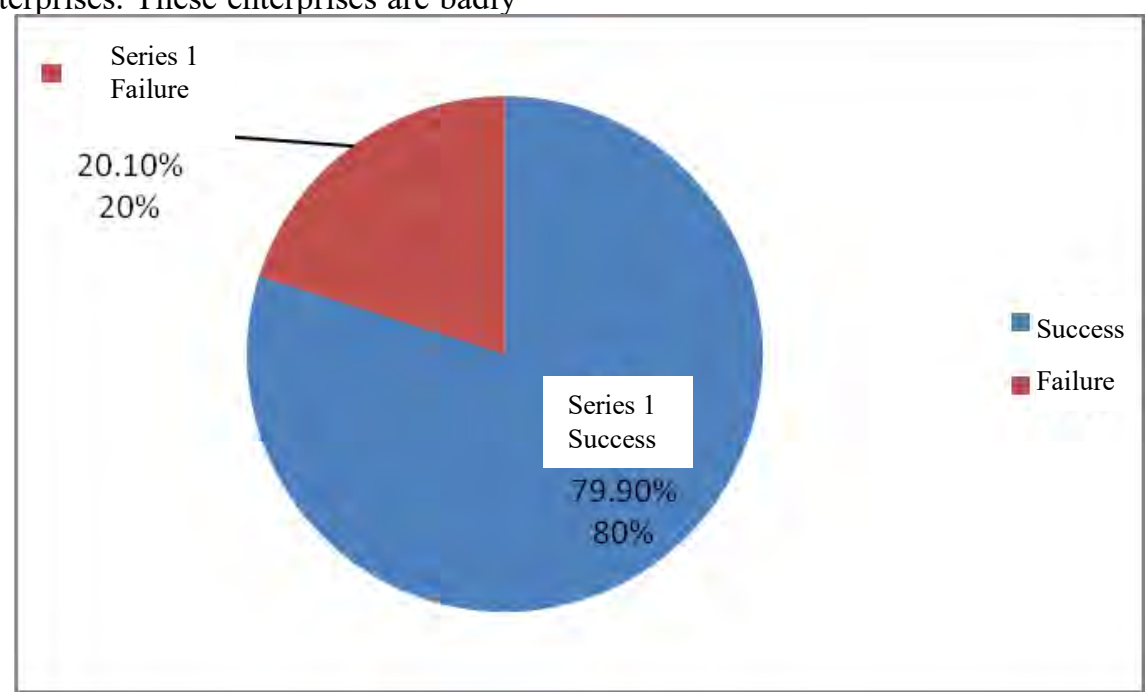

Fig. 2. Schematic diagram of success ratio of loan.

2) Inadequate construction of relevant laws and regulations: The causes of the financing difficulties of SMEs include financial sectors' little interest in financing due to the lack of confidence in SMEs. Besides, government departments pay more attention to large enterprises than SMEs, which is also the crucial reason for financing difficulties of SMEs [6]. Specifically, at this stage, many governments attach more importance to the operation and development of large enterprises when they focus on the development of enterprises. Therefore, the formulation of laws and regulations on the promotion and support of large enterprises is relatively perfect. Relatively, in terms of supporting the development of SMEs, although relevant departments have expressed concerns and attention in the slogan, real support and attention to SMEs are relatively few. The construction of relevant laws and regulations is insufficient, and the relevant guarantee act has few management and regulations for SMEs. As a result, legal support for SMEs is inadequate, and illegal financing is easy to occur, which results in that financing credibility of SMEs decreases, and ultimately, it can not guarantee that SMEs will be attractive enough in financing, thus causing the financing difficulties of SMEs.

\section{SOlutions to THE FinANCING DifficUlties OF SMES}

To overcome financing difficulties of SMEs, we will formulate corresponding solutions. From the perspective of standardizing the internal governance structure of enterprises and optimizing the collaboration of external institutions, we can improve the financing difficulties of enterprises by focusing on the following countermeasures:

\section{A. Standardizing the Internal Governance of Enterprises}

In improving the financing difficulties of SMEs, the development potential of SMEs themselves is the key to enhance the attractiveness of financing. In order to effectively enhance the financing attraction of SMEs, we should pay attention to governance structure and credit awareness, and the improvement of internal governance structure of enterprises will be shown as follows:

1) Optimizing governance organizations: When solving the financing difficulties of SMEs, the key to enhancing the attractiveness of SMEs financing is to optimize the internal governance structure [7]. In this respect, in order to ensure the scientific, standardized and rationalized governance of SMEs, it is crucial to improve family management structure at the present stage, eliminate human management and nepotism management, and clear the relationship between rights, responsibilities and interests. For example, we should adopt the mode of "using the wise and employing the capable" and select suitable talents as required by posts, and we should not fear "outsiders" who do not do their best for the enterprise, and make more use of incentives by means of the combination of material incentives and spiritual incentive, so as to enhance the trust and loyalty of "outsiders" to the enterprise, transform "outsiders" into "relatives", and build a reasonable chain of mutual benefits. This is the key to truly promoting the 
development of enterprises and stabilizing the internal governance structure of enterprises. Therefore, enterprise managers should make great efforts to strengthen their own management consciousness, so that they can establish a governance structure suitable for enterprise development under the guidance of correct management consciousness. Enterprises should strictly prohibit the phenomenon of cronyism, employ or appoint people according to their merits, and dispatch high-quality talents with ideas, abilities and principles to work posts, to guarantee that enterprises' internal governance can be scientific and external investors' confidence in enterprise development can be enhanced.

2) Enhancing credit consciousness: Many drawbacks of financial management in SMEs have greatly affected the trust of external investors in SMEs' operation. Therefore, to enhance the confidence of external investors on SMEs, SMEs should pay attention to the construction of enterprise credit image, so as to enhance the investment confidence of external investors in SMEs. To be specific, at the present stage, SMEs should take notice of enhancing their credit awareness and recognizing the importance of information disclosure when building their investment credit image, so that they can really increase the disclosure of enterprise financial information, make enterprise financing more transparent, and ensure that all guarantee institutions and credit organizations can better grasp the credit status of enterprises and establish a good credit impression on enterprises [8]. These measures will help the institutions to comprehensively grasp various information of enterprises before the enterprises put forward their loan application, and they can timely combine various financial information to assess and determine enterprises' loan application, and the success rate of enterprise loan will be greatly enhanced.

\section{B. Optimizing the Collaboration of External Institutions}

The improvement of the enterprise's own governance structure can help SMEs take more scientific methods to use financing capital, and the increase of social attention to the financing of SMEs can bring more financing channels for them. To this end, external institutions should start from the following aspects to build a scientific financing cooperation system:

1) Strengthening financial institution support: In the process of resolving the financing difficulties of SMEs, of course, it is vital for enterprises to manage their own funds and establish their credit image. But what is more important is that modern financial institutions raise their concern and interests in SMEs' financing activities. Therefore, when SMEs carry out financing activities, relevant financial institutions should focus more on SMEs' development potential, look for scientific methods that are conducive to the development of SMEs and ensure the safety of capital investment, take credit system and business performance as evaluation criteria, support SMEs with potential, and invest capital to promote the development of SMEs [9]. For example, in terms of SMEs of "new three board" type, financial institutions should understand the development projects of such enterprises and evaluate their project value to decide whether to invest in them. Financial institutions should not deny the development potential of enterprises because of their small scale. They should fully recognize the future development value of enterprises, and then decide whether to invest or not. Generally speaking, by means of potential assessment for financing activities, it can better play the economic promotion role of financial institutions, and provide more solid backup support for the development of SMEs. However, it should be noted that in order to truly understand the basic situation of SMEs, financial institutions should urge the whole industry to establish a sound credit evaluation system and credit inquiry system, and master the past lending and financing situation of SMEs to evaluate whether the enterprise is trustworthy, so as to ensure the scientificity and security of financing investment.

2) Optimizing relevant laws and regulations: In the process of scientifically solving the financing difficulties of SMEs, in addition to increasing the attention and support of financial institutions for the development of SMEs, the relevant departments of the government should also attach importance to supporting and supervising the financing activities of SMEs, so as to ensure that the financing activities of SMEs are more scientific, legal, and influential[10]. To be specific, at this stage, the relevant departments should urge the relevant legislative institutions to repair the financing acts of SMEs according to their financing needs, and increase the new attraction of SMEs by means of legislative support. For example, we can establish a high-quality guarantee liability system, scientifically and efficiently apply Guarantee Law to the support and protection of corporate financing, thereby enhancing the legitimacy and compliance of corporate financing and increasing investor' investment confidence. In addition, we can increase the investigation and punishment for the illegal financing activities, comprehensively rectify the financing market, and eliminate some non-compliant, unreasonable and illegal financing activities from the market, so as to improve the public's view on financing, and the government departments should make positive publicity and protect the financing activities of SMEs, which help SMEs to better carry out financing activities and receive support from social funds.

\section{CONCLUSION}

To sum up, as one of the main supports of China's market economy, SMEs can effectively ensure the scientific and efficient development of their financing activities so as to ensure the stability of China's market economy development. However, from the current situation of financing activities of SMEs, financing difficulties are an important issue they have to face. Therefore, in order to truly promote the financing development of SMEs, this paper analyzes the causes of financing difficulties of SMEs, grasps the factors of financing difficulties of enterprises from internal situation and external 
market environment, puts forwards some solutions to optimize the financing environment and improve financing status, in order to improve the financing quality of SMEs and solve the practical problems of financing difficulties of SMEs.

\section{REFERENCES}

[1] Wu Shunmeng. Research on Solutions to Financing Difficulties of Small and Medium-sized Enterprises from the Perspective of Financial Innovation [J]. China Market, 2018 (23): 183-184. (in Chinese).

[2] Luo Hongxia. Analysis of the Reasons for the Difficulties in Financing of Small and Medium-sized Enterprises and the Countermeasures [J]. China Business \& Trade, 2018 (10): 55-56. (in Chinese)

[3] Liang Zhenmin. Current Development Path of Small and Medium-sized Enterprises in Shanghai in New Normal State of Economic Development [J]. Journal of Heilongjiang University of Technology (Comprehensive Edition), 2018, 18 (02): 64-68. (in Chinese)

[4] Xiao Xue. Analysis of Financing Problems and Countermeasures of Small and Medium-sized Enterprises in Hubei [J]. Pioneering with Science \& Technology Monthly, 2018, 31 (01): 42-44. (in Chinese)

[5] Huang Yunxia. Analysis on Financing Environment of Small and Medium-sized Enterprises in China and Countermeasure [J]. Baokanhuicui, 2018 (01): 232. (in Chinese)

[6] Yin Ruyan. Analysis on the Current Situation and Countermeasures of Financing of Small and Medium-sized Enterprises in China [J]. Modern Business, 2017 (32): 75-76. (in Chinese)

[7] Si Yuan. Analysis on the Influence of Internet Finance on Financing of Small and Medium-sized Enterprises and Countermeasures [J]. Journal of Liaoning Teachers College (Social Sciences Edition), 2017 (04): 1012. (in Chinese)

[8] Deng Suzhou. Quality Analysis and Improvement Countermeasures of Endogenous Financing of Small and Medium-sized Enterprise [J]. Market Modernization, 2017 (15): 122-123. (in Chinese)

[9] Anonymous. Research and Markets: Royalty Financing Agreements in Pharma, Biotech and Diagnostics[J]. M2 Presswire,2010.

[10] Fariba Fathirad, Daryoush Afzali, Ali Mostafavi. Bimetallic Pd-Zn nanoalloys supported on Vulcan XC-72R carbon as anode catalysts for oxidation process in formic acid fuel cell[J]. International Journal of Hydrogen Energy,2016,41(30). 